\title{
OPEN Effects of soil amendments on leaf anatomical characteristics of marigolds cultivated in cadmium-spiked soils
}

\author{
Alapha Thongchai ${ }^{1}$, Weeradej Meeinkuirt ${ }^{2,3 凶}$, Puntaree Taeprayoon $^{2}$ \& Isma-ae Chelong ${ }^{1}$
}

The marigolds (Tagetes spp.) in this study were classified as excluders for cadmium (Cd); however, their leaves also accumulated substantial $\mathrm{Cd}$ content. Among the experimental treatments (i.e., control, cattle manure, pig manure, and leonardite which served as soil amendments), pig manure resulted in significantly increased growth performance for all marigold cultivars as seen by relative growth rates (119-132.3\%) and showed positive effects on leaf anatomy modifications, e.g., thickness of spongy and palisade mesophyll, size of vein area and diameter of xylem cells. This may be due to substantially higher essential nutrient content, e.g., total nitrogen $(\mathrm{N})$ and extractable phosphorus $(P)$, in pig manure that aided all marigold cultivars, particularly the French cultivar which exhibited the highest relative growth rate (132.3\%). In the Cd-only treatment, cell disorganization was observed in vascular bundles as well as in palisade and spongy mesophyll, which may have been responsible for the lowest plant growth performance recorded in this study, particularly among the American and Honey cultivars (RGR $=73 \%$ and $77.3 \%$, respectively).

Organic amendments improve soil physicochemical factors and immobilize heavy metals in soil via adsorption and isolation of cationic compounds by forming stable complexes. Soil properties affecting the availability of cadmium $(\mathrm{Cd})$ include: Cd adsorption and desorption on iron $(\mathrm{Fe})$ and manganese $(\mathrm{Mn})$ oxides; redox potential (Eh); presence of both calcium carbonate and oxyhydroxides; $\mathrm{pH}$; organic matter (OM); ionic strength; ligand anions; cation exchange capacity (CEC); phosphorus (P); and the proportion of clay minerals and percentage of charged sites occupied by $\mathrm{Cd}$. Control of some of these properties can be employed to reduce Cd phytoavailability and decrease transfer of the metal into the food chain ${ }^{1,2}$. Furthermore, the OM content of animal manures (e.g., cattle, chicken, horse and bat) forms strong complexes with Cd resulting in the reduced mobility of Cd in soil and reduced leaching, decreasing both its toxicity and bioavailability. In one study the application of cattle manure to contaminated soil resulted in reduced Cd leaching by approximately $63 \%{ }^{3}$. Many researchers have indicated that leonardite serves as an exceptional substitute for mineral-based fertilizer given that it is rich in humic acid and fulvic acid (50-75\%). Application of leonardite (400 $\left.\mathrm{kg} \mathrm{ha}^{-1}\right)$ and inorganics (e.g., zeolite) or organic (e.g., animal manure) materials can substantially improve the physicochemical properties of soil, leading to increased crop yield and quality ${ }^{4,5}$.

The leaf is the major site of photosynthesis in most vascular plants, and leaf morphology and anatomy play crucial roles in photosynthesis efficiency. Other important leaf traits such as thickness and stomatal density directly influence metal tolerance and sensitivity ${ }^{6}$. Physiological function, such as leaf photosynthesis and respiration, are closely associated with the changes in leaf structure, chemical function and carbon balance; the character of the changes depends on plant species and cultivar, type of root, and environmental factors ${ }^{7}$. Cadmium is a non-essential element for plants that can be readily taken up by root systems and transported predominantly into the aerial parts of marigolds (Tagetes spp.) ${ }^{8}$. Elevated Cd concentrations reduce plant growth by limiting rate of photosynthesis, reducing stomatal size in the lower epidermis, and reducing density, mesophyll thickness and intercellular spaces in the mesophyll ${ }^{6,9}$. To some extent, heavy metals i.e., zinc ( $\left.\mathrm{Zn}\right)$, mercury ( $\left.\mathrm{Hg}\right)$, lead (Pb) and Cd may cause changes in trichome length and density on leaf surfaces ${ }^{10}$.

Studying anatomical modifications in leaves can help in understanding biological processes in plants regarding heavy metal tolerance and accumulation mechanisms; for instance, elevated heavy metal accumulation in

${ }^{1}$ Faculty of Science Technology and Agriculture, Yala Rajabhat University, Yala 95000, Thailand. ${ }^{2}$ Mahidol University, Nakhonsawan Campus, Nakhonsawan 60130, Thailand. ${ }^{3}$ Water and Soil Environmental Research Unit, Mahidol University, Nakhonsawan Campus, Nakhonsawan 60130, Thailand. ${ }^{\varpi}$ email: weeradej.mee@mahidol.ac.th 


\begin{tabular}{|c|c|c|c|c|c|}
\hline \multirow[b]{2}{*}{ Soil properties } & \multicolumn{5}{|l|}{ Treatment } \\
\hline & \begin{tabular}{|l|} 
Com-Ctrl \\
\end{tabular} & Cd-Alon & Cd-Pig & Cd-Catt & Cd-Leo \\
\hline Soil texture & Loam & Clay & Clay & Clay & Clay \\
\hline Soil pH & 6.5 & 7.1 & 6.8 & 7.1 & 6.8 \\
\hline $\operatorname{CEC~}\left(\mathrm{mol} \mathrm{kg}^{-1}\right)$ & 18.2 & 28.3 & 28.6 & 28.4 & 30.8 \\
\hline $\mathrm{OM}(\%)$ & 10.2 & 3.4 & 8.3 & 8.1 & 11.7 \\
\hline Total N (\%) & 0.4 & 0.2 & 0.5 & 0.4 & 0.5 \\
\hline Ext. P (\%) & 318.6 & 300.4 & 1483.2 & 400.2 & 322.4 \\
\hline Ext. K (\%) & 1121.4 & 521.4 & 1228.4 & 2444.3 & 5438 \\
\hline \multicolumn{6}{|l|}{ Before planting } \\
\hline Total $\mathrm{Cd}\left(\mathrm{mg} \mathrm{kg}^{-1}\right)$ & $1.9 \pm 0.2 \mathrm{bA}$ & $8.1 \pm 1.6 \mathrm{aA}$ & $8.3 \pm 0.7 \mathrm{aA}$ & $8.3 \pm 1.0 \mathrm{aA}$ & $7.4 \pm 1.0 \mathrm{aA}$ \\
\hline \multicolumn{6}{|l|}{ After plant harvest } \\
\hline Total $\mathrm{Cd}\left(\mathrm{mg} \mathrm{kg}^{-1}\right)$ & $0.9 \pm 0.1 \mathrm{bB}$ & $7.9 \pm 2.4 \mathrm{aA}$ & $7.8 \pm 1.2 \mathrm{aA}$ & $7.9 \pm 1.1 \mathrm{aA}$ & $7.0 \pm 1.1 \mathrm{abA}$ \\
\hline
\end{tabular}

Table 1. Physicochemical properties of the soils used in this study. CEC cation exchange capacity, OM organic matter, $N$ nitrogen, Ext. extractable, $P$ phosphorus, $K$ potassium, $C d$ cadmium. Values followed by the same letter are not significantly different; lower-case letters show the difference of $\mathrm{Cd}$ concentrations in soils among treatments (LSD, $p<0.05$ ); capital letters indicate the difference of Cd concentrations in soils before planting and after plant harvest (LSD, $p<0.05)$.

leaves is known to inhibit leaf transpiration rate, resulting in reduced plant growth and yields ${ }^{11,12}$. However, the deposition and desorption of heavy metals in leaves is known to vary by species, specific heavy metals content, speciation and certain key environmental factors, e.g., $\mathrm{pH}$, cation exchange capacity (CEC) and organic matter $(\mathrm{OM})$ content $^{13}$. Comparison of leaf anatomical characteristics among various plant species grown in heavy metal-enriched soil may help identify heavy metal accumulation and patterns of distribution, and in cataloguing the effects of heavy metal toxicity and tolerance. Many plant species exposed to Cd toxicity exhibit alterations in leaf anatomical structures, examples include chickpea (Cicer arientinum L.) and fenugreek (Trigonella foenumgraecum L. $)^{14}$. Furthermore, many reports indicate that the presence of certain essential nutrients in plant media can affect the modification of leaf anatomical characteristics. For example, Fe deficiency induces more numerous but smaller stomatal apertures in both upper and lower leaf surfaces. Similarly, large quantities of $\mathrm{Zn}$ have been found to cause significant reduction in epidermal cell size and area of vascular bundles, and disorganization of spongy parenchyma cells ${ }^{15}$.

The present study was carried out to investigate the effects of soil amendment applications on Cd accumulation in leaves, in particular the anatomical modifications in leaves of four marigold cultivars (Tagetes erecta L. e.g., Honey, American and Sunshine and T. patula L. e.g., French) grown in pot systems in a greenhouse environment.

\section{Results and discussion}

Physicochemical properties of soils. Selected physicochemical properties of soils utilized for this study are shown in Table 1. Texture of the control soil is loam, whereas the others (Cd soils) are clay. The different physicochemical properties of the experimental soils are due to both organic soil amendments and soil texture. The application of organic amendments increased soil $\mathrm{pH}$ and cation exchange capacity (CEC) values from 6.5 and $28.3 \mathrm{cmol} \mathrm{kg}^{-1}$ in the Cd-Alon treatment to $6.8-7.1$ and $28.4-30.8 \mathrm{cmol} \mathrm{kg}^{-1}$ in the Cd-enriched soil amended with organic amendments, respectively. The desirable soil $\mathrm{pH}$ for optimum plant cultivation varies in the range of 5.5-7.0 $0^{16}$. Soil pH is a key factor for plant growth as it can influence several physicochemical properties of soil which impact plant traits such as height, lateral spread, mass, flower size and shape, and pollen production ${ }^{17}$. The control soil was used in this study because it contained a very low concentration of Cd, and substantial concentrations of essential nutrients and OM that support plant growth (Table 1). The control soil amended with Osmocote showed a remarkably low CEC value; a factor of 1.6-1.7 times lower than any of the other treatments. The elevated CEC content in Cd-enriched soils led to $\mathrm{Cd}$ immobilization via sorption and precipitation mechanisms ${ }^{18}$. When comparing the differences in essential nutrients between the Cd-Alon soil and Cd soils with amendments, the organic amendments increased total nitrogen $(\mathrm{N})$, extractable phosphorus (Ext. $\mathrm{P})$, and extractable potassium (Ext. K) contents by approximately 1.5-2.5, 1.1-4.9, and 1-4.7 times, respectively. Highest total $\mathrm{N}$ and Ext. P contents were in the Cd-pig treatment $\left(0.5 \%\right.$ and $\left.1483.2 \mathrm{mg} \mathrm{kg}^{-1}\right)$. The Cd-cattle treatment also showed increased levels of Ext. P and Ext. K, at $400.2 \mathrm{mg} \mathrm{kg}^{-1}$ and $2444.3 \mathrm{mg} \mathrm{kg}^{-1}$, respectively.

Substantial OM contents were measured in the Cd-Leo and Com-Ctrl treatments $(10.2 \%$ and $11.7 \%$, respectively), whereas lowest OM content was in the Cd-Alon treatment (3.4\%). Humic substances originating from organic matter in leonardite can improve the physicochemical properties of soil and stimulate plant growth performance ${ }^{19}$. Rehman et al. ${ }^{20}$ indicated that increased OM content in amendments, applied in different combinations, could increase rice growth when high Cd-contaminated effluent water is applied to soil during planting.

Before planting, the spiked Cd resulted in significantly higher Cd contents in Cd-soils when compared with the control soil $(p<0.05)$. After plant harvest, Cd-soils showed a slight decrease in Cd content; however, there appears to be no statistically significant difference $(p>0.05)$. Several researchers have reported that organic soil amendment practices in $\mathrm{Cd}$ and $\mathrm{Zn}$ co-enriched soils were used to immobilize $\mathrm{Cd}$ as stable forms thus reducing 


\begin{tabular}{|c|c|c|c|c|c|}
\hline \multirow[b]{2}{*}{ Plant } & \multirow[b]{2}{*}{ Treatment } & \multicolumn{4}{|c|}{ Dry biomass production ( $\mathrm{g} \mathrm{dw}$ ) } \\
\hline & & Stem & Leaf & Root & Total \\
\hline \multirow{5}{*}{ French } & Com-Ctrl & $3.9 \pm 1.1 \mathrm{bC}$ & $0.8 \pm 0.2 \mathrm{bC}$ & $1.8 \pm 1.0 \mathrm{bB}$ & $6.4 \pm 0.6 \mathrm{bC}$ \\
\hline & Cd-Alon & $1.9 \pm 0.8 \mathrm{bcB}$ & $0.1 \pm 0.0 \mathrm{cB}$ & $0.3 \pm 0.2 \mathrm{bAB}$ & $2.3 \pm 0.9 \mathrm{cB}$ \\
\hline & Cd-Pig & $27.2 \pm 3.2 \mathrm{aB}$ & $2.3 \pm 0.5 \mathrm{aC}$ & $6.9 \pm 4.2 \mathrm{aA}$ & $36.3 \pm 4.3 \mathrm{aB}$ \\
\hline & Cd-Catt & $3.2 \pm 0.7 \mathrm{bcB}$ & $0.1 \pm 0.0 \mathrm{cB}$ & $0.3 \pm 0.1 \mathrm{bB}$ & $3.6 \pm 0.8 \mathrm{cB}$ \\
\hline & Cd-Leo & $1.9 \pm 0.4 \mathrm{cB}$ & $0.1 \pm 0.0 \mathrm{cA}$ & $0.2 \pm 0.1 \mathrm{bB}$ & $1.7 \pm 0.4 \mathrm{cC}$ \\
\hline \multirow{5}{*}{ Honey } & Com-Ctrl & $10.3 \pm 1.3 \mathrm{bA}$ & $1.1 \pm 0.3 \mathrm{bBC}$ & $2.4 \pm 0.2 \mathrm{bAB}$ & $13.8 \pm 1.7 \mathrm{bAB}$ \\
\hline & Cd-Alon & $3.0 \pm 0.7 \mathrm{cAB}$ & $0.3 \pm 0.1 \mathrm{cA}$ & $0.4 \pm 0.2 \mathrm{cA}$ & $3.7 \pm 0.9 \mathrm{cAB}$ \\
\hline & Cd-Pig & $35.3 \pm 8.8 \mathrm{aB}$ & $3.0 \pm 0.5 \mathrm{aAB}$ & $4.5 \pm 2.3 \mathrm{aA}$ & $42.7 \pm 10.5 \mathrm{aB}$ \\
\hline & Cd-Catt & $1.1 \pm 0.5 \mathrm{cB}$ & $0.1 \pm 0.0 \mathrm{cB}$ & $0.2 \pm 0.1 \mathrm{cB}$ & $1.4 \pm 0.5 \mathrm{cB}$ \\
\hline & Cd-Leo & $3.4 \pm 0.8 \mathrm{cA}$ & $0.1 \pm 0.0 \mathrm{cB}$ & $0.4 \pm 0.1 \mathrm{cA}$ & $3.9 \pm 0.9 \mathrm{cAB}$ \\
\hline \multirow{5}{*}{ American } & Com-Ctrl & $7.3 \pm 1.9 \mathrm{bB}$ & $1.2 \pm 0.2 \mathrm{bB}$ & $3.6 \pm 1.3 \mathrm{bB}$ & $12.1 \pm 3.2 \mathrm{bB}$ \\
\hline & Cd-Alon & $2.1 \pm 0.8 \mathrm{cB}$ & $0.1 \pm 0.0 \mathrm{cB}$ & $0.2 \pm 0.1 \mathrm{cB}$ & $2.4 \pm 0.9 \mathrm{cB}$ \\
\hline & Cd-Pig & $31.3 \pm 6.7 \mathrm{aB}$ & $2.6 \pm 0.4 \mathrm{aBC}$ & $8.1 \pm 1.8 \mathrm{aA}$ & $42.0 \pm 5.9 \mathrm{aB}$ \\
\hline & Cd-Catt & $3.6 \pm 2.4 \mathrm{bcB}$ & $0.3 \pm 0.1 \mathrm{cB}$ & $0.4 \pm 0.2 \mathrm{cB}$ & $4.3 \pm 2.5 \mathrm{cB}$ \\
\hline & Cd-Leo & $1.7 \pm 0.9 \mathrm{cB}$ & $0.2 \pm 0.1 \mathrm{cA}$ & $0.3 \pm 0.1 \mathrm{cA}$ & $2.2 \pm 1.1 \mathrm{cAB}$ \\
\hline \multirow{5}{*}{ Sunshine } & Com-Ctrl & $11.7 \pm 1.0 \mathrm{bcA}$ & $1.8 \pm 0.3 \mathrm{bA}$ & $2.2 \pm 1.5 \mathrm{bAB}$ & $15.6 \pm 2.3 \mathrm{bcA}$ \\
\hline & Cd-Alon & $4.4 \pm 1.9 \mathrm{cA}$ & $0.2 \pm 0.0 \mathrm{cAB}$ & $0.4 \pm 0.2 \mathrm{bA}$ & $5.1 \pm 2.1 \mathrm{cA}$ \\
\hline & Cd-Pig & $55.5 \pm 17.2 \mathrm{aA}$ & $3.5 \pm 0.5 \mathrm{aA}$ & $7.1 \pm 5.8 \mathrm{aA}$ & $66.1 \pm 22.8 \mathrm{aA}$ \\
\hline & Cd-Catt & $21.3 \pm 8.9 \mathrm{bA}$ & $1.6 \pm 0.5 \mathrm{bA}$ & $1.7 \pm 1.1 \mathrm{bA}$ & $24.6 \pm 9.6 \mathrm{bA}$ \\
\hline & Cd-Leo & $3.7 \pm 2.0 \mathrm{cA}$ & $0.2 \pm 0.1 \mathrm{cA}$ & $0.3 \pm 0.1 \mathrm{bA}$ & $4.2 \pm 2.2 \mathrm{cA}$ \\
\hline
\end{tabular}

Table 2. Dry biomass production of the study plants $(n=5)$. Values followed by the same letter are not significantly different; lower-case letters show the difference of treatments of the same cultivar (LSD, $p<0.05$ ); capital letters indicate the difference in growth performance among marigold cultivars within the same treatment (LSD: $p<0.05$ ).

mobility and bioavailability in contaminated agricultural soils, thereby markedly safeguarding human health and protecting the local environment ${ }^{2}$. Furthermore, Cd content decreased slightly to 2.1 times the level in the Com-Ctrl treatment $(p<0.05)$, which falls within the soil quality criteria for agricultural soil $\left(<1 \mathrm{mg} \mathrm{kg}^{-1}\right)^{21}$.

Plant growth performance. The order of dry biomass plant tissue quantities was as follows: stems $>$ roots $>$ leaves. Significant differences in dry biomass were recorded from cultivars grown in the Cd-pig treatment across all marigold cultivars ( $p<0.05$; Table 2). The Sunshine cultivar had higher dry biomass content in comparison to other marigold cultivars by factors of 1.5 to 47.2 times. These results are consistent with a previous study ${ }^{8}$. Substantial increase in dry biomass content was also measured in the Cd-cattle treatment for the Sunshine cultivar $(24.6 \mathrm{~g})$. The nutrient content of organic amendments such as pig and cattle manure enhance soil $\mathrm{N}$ concentrations considerably, which helps induce both plant growth and yield. Therefore, available $\mathrm{N}$ from animal manures is considered to have substantial potential and is valuable for optimum plant growth in contaminated soils. Nitrogen is also usually added as a supplement in various organic fertilizers, either alone or in combination with inorganic fertilizers ${ }^{22}$. The substantial OM content in the Cd-Leo treatment did not exhibit a commensurate influence on plant growth performance in this study. Although soil amendments minimize the detrimental effects of heavy metal exposure to plant cultivars, high levels of heavy metals can decrease plant biomass which might be a consequence of heavy metal stress, oxidative damage and increased membrane permeability $^{23,24}$.

Increased plant growth and biomass in Cd-contaminated soils treated with organic amendments were in agreement with the results of Gul et al. ${ }^{25}$. They reported that increased biomass of Pelargonium hortorum L.H. Bailey (17.9-26.6\%) grown in Pb-contaminated soils was dependent upon application of compost. The descending order of dry biomass production in marigold cultivars for all treatments was as follows: Sunshine $>$ Honey $>$ American $>$ French, whereas the Cd-Catt treatment showed a slightly different pattern: Sunshine $>$ American $>$ Honey $>$ French (Table 2 ). The observed trends were slightly different for the highest $\%$ RGR values for the study plants as follows: French $>$ Sunshine $>$ American $>$ Honey (Fig. 1). Furthermore, significant differences in mean values of percentage relative growth rate were observed in specimens grown in the Cd-Pig treatments for all marigold cultivars $(p<0.05)$.

Cadmium accumulation in plant tissue. Among Cd treatments, all cultivars accumulated high quantities of Cd in whole plants, particularly in the Cd-Alon treatment for the French and Sunshine cultivars, and the Cd-Catt treatment for Honey and American treatments, ranging from 27.6 to $49.1 \mathrm{mg} \mathrm{kg}^{-1}$ (Table 3). However, marigold tissue (roots, stems, leaves and whole plant) in the Com-Ctrl treatment possessed the lowest Cd contents in all marigold cultivars $(p<0.05)$. Furthermore, all marigold cultivars accumulated lowest levels of Cd in the Cd-Pig treatment. Marigold roots accumulated the highest Cd followed by stems and then leaves, respec- 


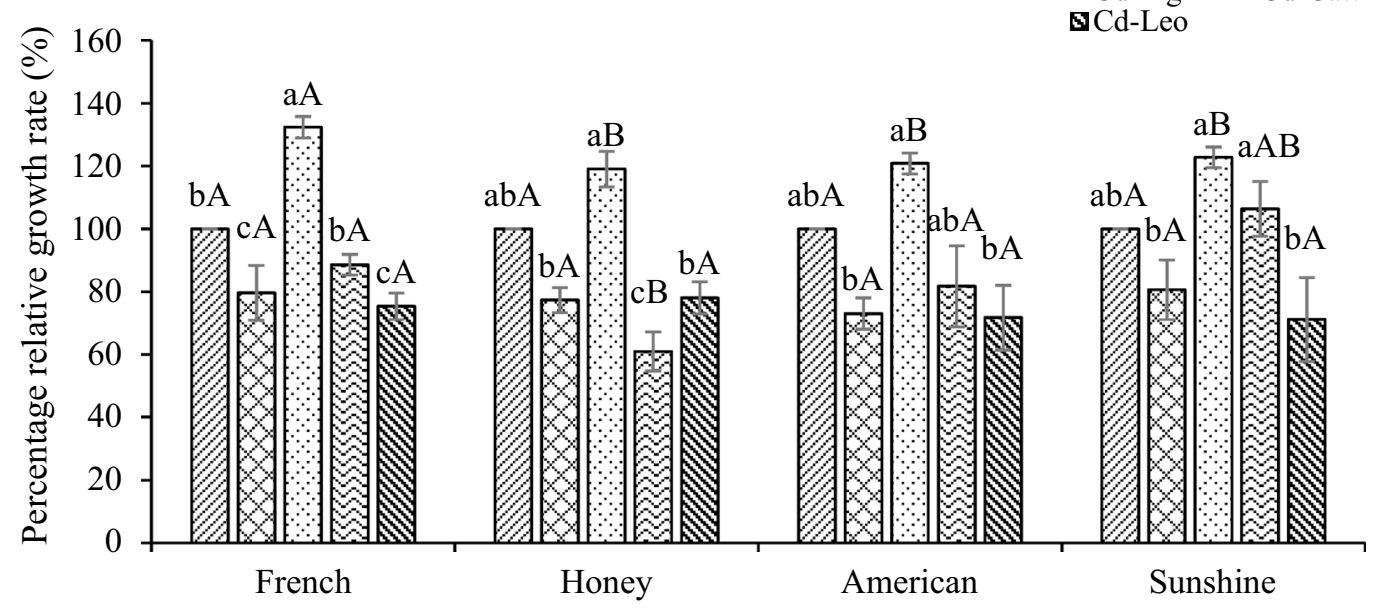

Figure 1. Percentage relative growth rate values of the study plants $(n=5)$. Values followed by the same letter are not significantly different; lower-case letters show the difference of treatments of the same cultivar (LSD, $p<0.05$ ); capital letters indicate the difference in percentage relative growth rate values among marigold cultivars within the same treatment (LSD: $p<0.05$ ).

\begin{tabular}{|c|c|c|c|c|c|}
\hline \multirow[b]{2}{*}{ Marigold cultivar } & \multirow[b]{2}{*}{ Treatment } & \multicolumn{4}{|c|}{ Cd accumulation in plant $\left(\mathrm{mg} \mathrm{kg}^{-1}\right)$} \\
\hline & & Root & Stem & Leaf & Whole plant \\
\hline \multirow{5}{*}{ French } & Com-Ctrl & $4.0 \pm 1.1 \mathrm{dA}$ & $1.7 \pm 0.4 \mathrm{cA}$ & $2.3 \pm 0.6 \mathrm{cA}$ & $2.5 \pm 0.4 \mathrm{cA}$ \\
\hline & Cd-Alon & $50.4 \pm 7.0 \mathrm{aAB}$ & $37.4 \pm 4.2 \mathrm{aA}$ & $38.2 \pm 3.7 \mathrm{aA}$ & $39.0 \pm 3.0 \mathrm{aA}$ \\
\hline & Cd-Pig & $28.5 \pm 1.2 \mathrm{cA}$ & $24.0 \pm 2.0 \mathrm{bA}$ & $25.6 \pm 1.9 \mathrm{bA}$ & $22.4 \pm 1.0 \mathrm{bA}$ \\
\hline & Cd-Catt & $40.1 \pm 6.0 \mathrm{bAB}$ & $22.3 \pm 2.7 \mathrm{bA}$ & $25.3 \pm 0.4 \mathrm{bAB}$ & $34.0 \pm 6.4 \mathrm{abA}$ \\
\hline & Cd-Leo & $39.4 \pm 3.1 \mathrm{bB}$ & $25.6 \pm 4.1 \mathrm{bA}$ & $26.9 \pm 2.8 \mathrm{bA}$ & $30.9 \pm 4.1 \mathrm{bA}$ \\
\hline \multirow{5}{*}{ Honey } & Com-Ctrl & $3.7 \pm 1.0 \mathrm{dA}$ & $1.4 \pm 0.4 \mathrm{cA}$ & $1.8 \pm 0.7 \mathrm{cA}$ & $2.1 \pm 0.8 \mathrm{cA}$ \\
\hline & Cd-Alon & $39.7 \pm 10.0 \mathrm{abB}$ & $17.4 \pm 1.7 \mathrm{abC}$ & $23.5 \pm 2.8 \mathrm{aB}$ & $30.8 \pm 3.6 \mathrm{aB}$ \\
\hline & Cd-Pig & $19.9 \pm 4.0 \mathrm{cB}$ & $10.1 \pm 3.4 \mathrm{bBC}$ & $16.6 \pm 2.6 \mathrm{bB}$ & $18.0 \pm 3.3 \mathrm{bAB}$ \\
\hline & Cd-Catt & $46.4 \pm 13.2 \mathrm{aAB}$ & $20.7 \pm 3.0 \mathrm{aA}$ & $26.8 \pm 0.4 \mathrm{aAB}$ & $34.5 \pm 5.2 \mathrm{aA}$ \\
\hline & Cd-Leo & $32.1 \pm 3.7 \mathrm{bC}$ & $13.8 \pm 2.1 \mathrm{bB}$ & $19.0 \pm 0.8 \mathrm{bB}$ & $22.5 \pm 2.4 \mathrm{abB}$ \\
\hline \multirow{5}{*}{ American } & Com-Ctrl & $3.9 \pm 1.3 \mathrm{cA}$ & $1.6 \pm 0.3 \mathrm{dA}$ & $1.9 \pm 0.6 \mathrm{dA}$ & $2.3 \pm 0.6 \mathrm{dA}$ \\
\hline & Cd-Alon & $50.5 \pm 4.2 \mathrm{aA}$ & $27.5 \pm 4.0 \mathrm{abB}$ & $37.0 \pm 2.8 \mathrm{aA}$ & $41.5 \pm 3.6 \mathrm{aA}$ \\
\hline & Cd-Pig & $18.8 \pm 4.0 \mathrm{bB}$ & $12.8 \pm 2.6 \mathrm{cB}$ & $16.3 \pm 2.6 \mathrm{cB}$ & $17.7 \pm 3.0 \mathrm{cB}$ \\
\hline & Cd-Catt & $58.1 \pm 10.2 \mathrm{aA}$ & $29.5 \pm 4.2 \mathrm{aA}$ & $37.8 \pm 6.8 \mathrm{aA}$ & $49.1 \pm 12.2 \mathrm{aA}$ \\
\hline & Cd-Leo & $52.3 \pm 5.7 \mathrm{aA}$ & $23.6 \pm 6.1 \mathrm{bA}$ & $29.5 \pm 4.8 \mathrm{bA}$ & $33.5 \pm 6.2 \mathrm{bA}$ \\
\hline \multirow{5}{*}{ Sunshine } & Com-Ctrl & $4.3 \pm 1.3 \mathrm{cA}$ & $1.6 \pm 0.3 \mathrm{cA}$ & $2.1 \pm 0.7 \mathrm{cA}$ & $2.9 \pm 0.6 \mathrm{cA}$ \\
\hline & Cd-Alon & $48.3 \pm 4.8 \mathrm{aAB}$ & $18.6 \pm 2.4 \mathrm{aC}$ & $23.2 \pm 4.4 \mathrm{aB}$ & $27.6 \pm 4.3 \mathrm{aB}$ \\
\hline & Cd-Pig & $20.5 \pm 3.9 \mathrm{bB}$ & $8.0 \pm 1.9 \mathrm{bC}$ & $9.2 \pm 1.9 \mathrm{bC}$ & $15.8 \pm 3.0 \mathrm{bB}$ \\
\hline & Cd-Catt & $23.1 \pm 3.8 \mathrm{bB}$ & $10.7 \pm 2.4 \mathrm{bB}$ & $13.0 \pm 1.7 \mathrm{bB}$ & $17.3 \pm 3.4 \mathrm{bA}$ \\
\hline & Cd-Leo & $19.4 \pm 2.7 \mathrm{bD}$ & $9.6 \pm 2.7 \mathrm{bB}$ & $11.7 \pm 1.3 \mathrm{bC}$ & $14.5 \pm 2.7 \mathrm{bC}$ \\
\hline
\end{tabular}

Table 3. Cd accumulation in different plant tissues from the four marigold cultivars $(n=5)$. Values followed by the same letter are not significantly different; lower-case letters show the difference of treatments of the same cultivar (LSD, $p<0.05$ ); capital letters indicate the difference in Cd accumulation performance among marigold cultivars within the same treatment (LSD: $p<0.05$ ).

tively, which is consistent with a previous study ${ }^{8}$. This plant exhibited excluder potential, that is, the propensity to accumulate $\mathrm{Cd}$ in lower concentrations in above-ground parts compared to roots ${ }^{26}$. Previous research has indicated that compost-amended soils decreased Cd bioavailability by approximately $50 \%$ in the hyperaccumulator P. hortorum, whereas compost addition reduced lead $(\mathrm{Pb})$ accumulation in shoots and roots by $33 \%$ and $28 \%$, respectively ${ }^{23,27}$. Furthermore, the application of organic amendments may result in restricted translocation of soluble Cd from root to shoot of the tested plants. The rather high OM content and soil $\mathrm{pH}$ increase Cd retention 


\begin{tabular}{|c|c|c|c|c|c|c|}
\hline Marigold cultivar & Treatment & Mid-vein area $\left(\mu \mathrm{m}^{2}\right)$ & $\begin{array}{l}\text { Adaxial-epidermis } \\
\text { thickness }(\mu \mathrm{m})\end{array}$ & $\begin{array}{l}\text { Abaxial-epidermis } \\
\text { thickness }(\mu \mathrm{m})\end{array}$ & Mesophyll thickness $(\mu \mathrm{m})$ & $\begin{array}{l}\text { Diameter of xylem cell } \\
(\mu \mathrm{m})\end{array}$ \\
\hline \multirow{5}{*}{ French } & Com-Ctrl & $7731.1 \pm 6488.6 \mathrm{bB}$ & $13.7 \pm 1.5 \mathrm{cAB}$ & $17.6 \pm 2.2 \mathrm{aA}$ & $289.7 \pm 79.0 \mathrm{aA}$ & $12.7 \pm 1.0 \mathrm{bA}$ \\
\hline & \begin{tabular}{|l|} 
Cd-Alon \\
\end{tabular} & $3042.9 \pm 2079.7 \mathrm{bC}$ & $18.0 \pm 1.5 \mathrm{bA}$ & $23.8 \pm 3.0 \mathrm{aA}$ & $223.3 \pm 66.8 \mathrm{abA}$ & $11.3 \pm 10.7 \mathrm{bA}$ \\
\hline & Cd-Pig & $24,694.5 \pm 4212.1 \mathrm{aAB}$ & $21.3 \pm 2.8 \mathrm{aA}$ & $23.0 \pm 10.8 \mathrm{aA}$ & $283.9 \pm 67.4 \mathrm{abAB}$ & $15.2 \pm 2.5 \mathrm{aA}$ \\
\hline & Cd-Catt & $4723.9 \pm 2496.2 \mathrm{bB}$ & $15.7 \pm 1.0 \mathrm{bcA}$ & $16.5 \pm 1.6 \mathrm{aA}$ & $199.6 \pm 14.6 \mathrm{abBC}$ & $9.9 \pm 4.1 \mathrm{cA}$ \\
\hline & Cd-Leo & $8742.1 \pm 2090.1 \mathrm{bB}$ & $14.9 \pm 1.1 \mathrm{bcA}$ & $16.8 \pm 5.6 \mathrm{aAB}$ & $182.2 \pm 43.8 \mathrm{bB}$ & $13.7 \pm 3.3 \mathrm{abA}$ \\
\hline \multirow{5}{*}{ Honey } & Com-Ctrl & $7191.4 \pm 1333.3 \mathrm{bB}$ & $18.3 \pm 4.0 \mathrm{aA}$ & $16.2 \pm 3.1 \mathrm{abA}$ & $219.8 \pm 24.1 \mathrm{bAB}$ & $11.4 \pm 3.7 \mathrm{abA}$ \\
\hline & Cd-Alon & $7877.0 \pm 3700.7 \mathrm{bB}$ & $13.7 \pm 2.0 \mathrm{aAB}$ & $12.2 \pm 2.6 \mathrm{abC}$ & $154.4 \pm 34.3 \mathrm{bB}$ & $12.0 \pm 2.5 \mathrm{abA}$ \\
\hline & Cd-Pig & $25,043.4 \pm 10,954.3 \mathrm{aAB}$ & $18.8 \pm 7.3 \mathrm{aA}$ & $17.4 \pm 5.6 \mathrm{aA}$ & $341.4 \pm 83.6 \mathrm{aA}$ & $17.1 \pm 7.1 \mathrm{aA}$ \\
\hline & Cd-Catt & $12,205.9 \pm 5786.5 \mathrm{bB}$ & $13.9 \pm 1.5 \mathrm{aA}$ & $17.9 \pm 6.4 \mathrm{aA}$ & $371.5 \pm 82.4 \mathrm{aA}$ & $14.7 \pm 5.8 \mathrm{abA}$ \\
\hline & Cd-Leo & $4009.3 \pm 2894.0 \mathrm{bC}$ & $7.3 \pm 1.9 \mathrm{bB}$ & $11.0 \pm 2.5 \mathrm{bB}$ & $189.4 \pm 37.7 \mathrm{bB}$ & $9.4 \pm 2.2 \mathrm{bA}$ \\
\hline \multirow{5}{*}{ American } & Com-Ctrl & $7713.7 \pm 2121.1 \mathrm{cB}$ & $17.7 \pm 5.4 \mathrm{aA}$ & $15.4 \pm 5.7 \mathrm{abA}$ & $151.6 \pm 31.0 \mathrm{bcB}$ & $11.0 \pm 1.2 \mathrm{bcA}$ \\
\hline & Cd-Alon & $7005.2 \pm 1026.8 \mathrm{cBC}$ & $17.0 \pm 4.3 \mathrm{aA}$ & $18.6 \pm 4.5 \mathrm{aAB}$ & $166.2 \pm 25.0 \mathrm{bB}$ & $9.0 \pm 3.0 \mathrm{cB}$ \\
\hline & Cd-Pig & $15,582.9 \pm 5516.9 \mathrm{aB}$ & $13.9 \pm 4.8 \mathrm{aA}$ & $19.1 \pm 4.1 \mathrm{aA}$ & $235.9 \pm 24.3 \mathrm{aB}$ & $15.8 \pm 4.2 \mathrm{aA}$ \\
\hline & Cd-Catt & $12,208.9 \pm 3700.8 \mathrm{abB}$ & $13.5 \pm 2.8 \mathrm{aA}$ & $15.9 \pm 2.8 \mathrm{abA}$ & $132.9 \pm 14.0 \mathrm{cC}$ & $13.7 \pm 4.1 \mathrm{abA}$ \\
\hline & Cd-Leo & $8194.7 \pm 2526.4 \mathrm{bcB}$ & $13.0 \pm 2.7 \mathrm{aA}$ & $12.8 \pm 2.9 \mathrm{bAB}$ & $173.4 \pm 15.6 \mathrm{bB}$ & $9.8 \pm 3.2 \mathrm{bcA}$ \\
\hline \multirow{5}{*}{ Sunshine } & Com-Ctrl & $21,444.5 \pm 5608.7 \mathrm{bA}$ & $12.1 \pm 3.8 \mathrm{bB}$ & $14.9 \pm 3.4 \mathrm{aA}$ & $225.5 \pm 77.9 \mathrm{bAB}$ & $13.6 \pm 2.9 \mathrm{abcA}$ \\
\hline & Cd-Alon & $15,969.8 \pm 2671.7 \mathrm{bA}$ & $11.5 \pm 3.9 \mathrm{bB}$ & $14.1 \pm 2.9 \mathrm{aBC}$ & $262.8 \pm 19.9 \mathrm{bA}$ & $11.3 \pm 2.6 \mathrm{cA}$ \\
\hline & \begin{tabular}{|l|} 
Cd-Pig \\
\end{tabular} & $33,914.2 \pm 7148.8 \mathrm{aA}$ & $17.4 \pm 4.9 \mathrm{aA}$ & $17.0 \pm 3.0 \mathrm{aA}$ & $351.2 \pm 97.3 \mathrm{aA}$ & $17.4 \pm 3.2 \mathrm{aA}$ \\
\hline & Cd-Catt & $35,071.8 \pm 10,772.7 \mathrm{aA}$ & $18.4 \pm 2.8 \mathrm{aA}$ & $15.2 \pm 2.1 \mathrm{aA}$ & $270.2 \pm 32.6 \mathrm{abAB}$ & $15.3 \pm 3.4 \mathrm{abA}$ \\
\hline & Cd-Leo & $19,947.3 \pm 3052.6 \mathrm{bA}$ & $14.7 \pm 4.3 \mathrm{abA}$ & $18.8 \pm 7.1 \mathrm{aA}$ & $254.2 \pm 46.7 \mathrm{bA}$ & $12.6 \pm 2.8 \mathrm{bcA}$ \\
\hline
\end{tabular}

Table 4. Leaf anatomical characteristics among five marigold cultivars $(n=5)$. Values followed by the same letter are not significantly different; lower-case letters show the difference of treatments of the same cultivar (LSD, $p<0.05$ ); upper-case letters indicate the difference of leaf anatomical characteristics among marigold cultivars within the same treatment (LSD, $p<0.05)$.

capacity, and thus decrease Cd solubility and bioavailability in soils ${ }^{23,27}$, as seen the remarkably low values in the treatments amended with organic amendments, particularly Cd-Pig and Cd-Leo treatments.

Influence of soil amendments on leaf anatomical changes. The leaves of four marigold cultivars showed slight anatomical modification in the Com-Ctrl and amended treatments (Table 4). High accumulation of $\mathrm{Cd}$ in leaves from the hyperaccumulating plants (e.g., marigold cultivars) varies according to plant genotype, $\mathrm{Cd}$ speciation and Cd quantities. Leaves can, however, potentially be seriously injured as a result of Cd toxicity ${ }^{28}$. Typically, elevated heavy metal content causes a decrease in the diameter and number of xylem cells, which has been reported in similar studies of certain terrestrial plant species, e.g., leaves of Triticum aestivum cv. Ekiz under chromium (Cr) stress ${ }^{29}$. Such phenomena are somewhat consistent with the present study, as leaf anatomical characteristics in the Cd-Alon treatment for some marigold cultivars showed remarkably smaller major vein areas (e.g., French, American and Sunshine cultivars) and diameter of xylem cells (American and Sunshine cultivars), compared to other treatments.

Large values for major vein area and xylem cell diameter were found in plants cultivated in the Cd-Pig treatment for all marigold cultivars $\left(15,582.9-33,914.2 \mu \mathrm{m}^{2}\right.$ and $15.2-17.4 \mu \mathrm{m}$, respectively $)(p<0.05)$, whereas almost all plants in Cd-Alon showed remarkably low values when compared to the other treatments. Plant characteristics showed significant differences in the American and Sunshine cultivars grown in the Cd-Pig and Cd-Alon treatments (2.2 and 2.1 times different, respectively). Lisa et al. ${ }^{14}$ found a smaller area of the vascular bundle in chickpea (C. arientinum) treated with Cd solution when compared to untreated plants. Application of organic amendments, particularly pig manure, can lead to increased mesophyll cell size and thickness of spongy parenchyma, sclerenchyma, phloem, and mesophyll in all treatments containing Cd, which can enable a greater capacity for $\mathrm{CO}_{2}$ retention in leaves, resulting in enhanced carbon availability and ultimately higher rates of photosynthesis ${ }^{6}$. To some extent, leaf mesophyll in the willow tree (Salix viminalis L.) stored Cd at higher concentrations when compared to veins ${ }^{28}$. However, in Arabidopsis helleri ssp. gemmifera Cd was localized in the vascular bundle rather than in the leaf mesophyll ${ }^{30}$.

In this study, greater mesophyll thickness was generally found in plants cultivated in the Cd-Pig treatment for all marigold cultivars (235.9-351.2 $\mu \mathrm{m})$; however, the highest value was in the Cd-Catt treatment for Honey cultivar $(371.5 \mu \mathrm{m})(p<0.05)$. To some extent, substantial mesophyll thickness in the Cd-Pig treatment may be linked with large palisade parenchyma and spongy parenchyma cells in the mesophyll, as well as with the influence of nutrients in soil ${ }^{31}$, as seen in Fig. 2C for Honey cultivar and compared to the Com-Ctrl treatment (Fig. 2A). The substantial total $\mathrm{N}$ and extractable $\mathrm{P}$ contents in pig manure may be key nutrients for growth of the study plants and their development into mature plants. These nutrients may also indirectly help enhance the size and number of vacuoles in mesophyll cells, thereby alleviating Cd toxicity, as free Cd and phytochelatin (PC)-Cd complexes can be sequestered and stored in the vacuole of leaf cells ${ }^{32}$. 

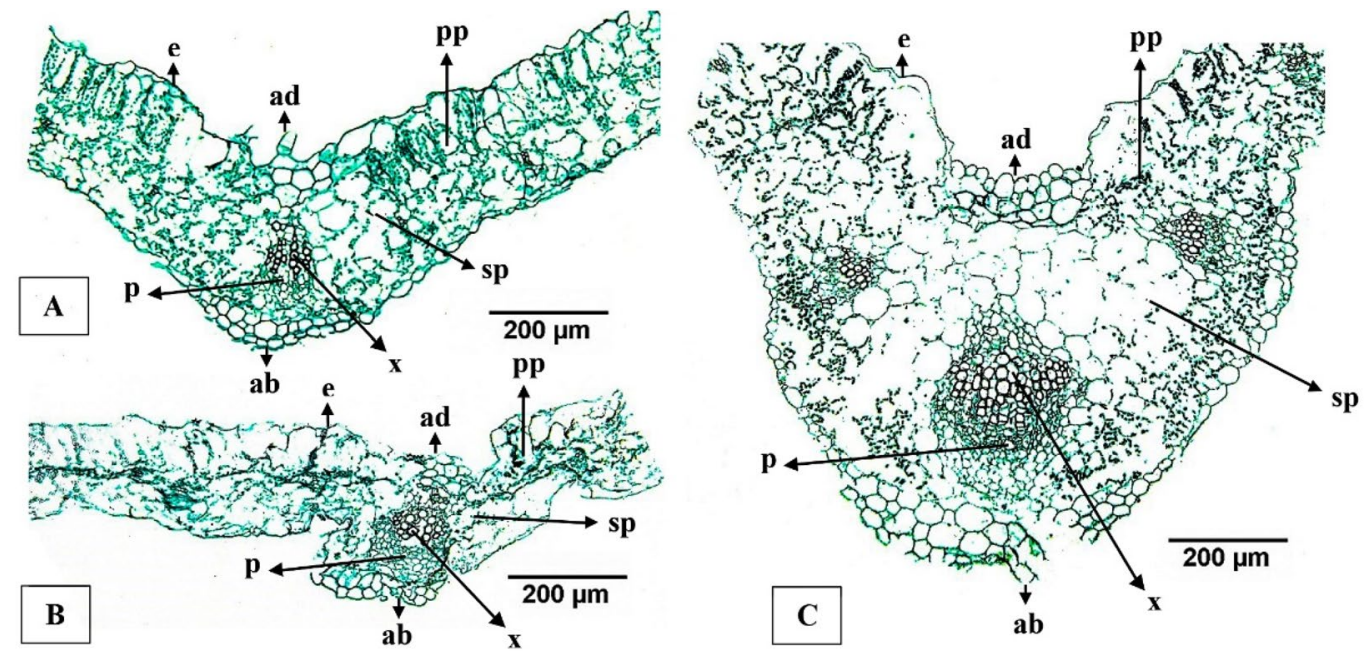

Figure 2. Leaf anatomy modifications occurred in Honey cultivar grown in different soil treatments (A) low Cd: Com-Ctrl treatment (B) soil without organic amendment: Cd-Alon treatment (C) amended soil: Cd-Pig treatment. $\mathrm{ad}=$ adaxial epidermis; $\mathrm{ab}=$ abaxial epidermis; $\mathrm{e}=$ epidermis; $\mathrm{pp}=$ palisade parenchyma; $\mathrm{sp}=\mathrm{spongy}$ parenchyma; $\mathrm{x}=\mathrm{xylem} ; \mathrm{p}=$ phloem.

In this study, French and Sunshine cultivars grown in the Com-Ctrl treatment had significantly lower epidermis thickness on the adaxial side when compared to those grown in the amended treatments $(p<0.05)$. Similar results were observed in Sunshine cultivar grown in the Cd-Alon treatment. Furthermore, epidermis thickness on the leaf abaxial side in the Cd-Pig and Cd-Catt treatments for Honey cultivar and in the Cd-Pig treatment for American cultivar showed slight differences in comparison to the Com-Ctrl $(p<0.05)$. Some evidence indicates that heavy metals present in the growth medium can lead to increased epidermal cell size, which increases quantities of heavy metals absorbed into the epidermal layer and subsequently on the cell wall of the epidermis. This strategy helps plants prevent uptake, translocation and sequestration of heavy metals, thus reducing heavy metal absorption and/or adsorption in mesophyll cells, and increasing rates of photosynthesis ${ }^{11}$. The significantly elevated levels of heavy metals on the epidermal cell walls, however, can cause deformation and breakdown of chloroplasts and many cell organelles, including cell walls of mesophyll ${ }^{33}$. Furthermore, an elevated soil Cd content could substantially reduce the photosynthetic rate in the mesophyll of the hybrid Pennisetum grass. However, the toxicity threshold for Cd in plants varies among plant species and within a species among subspecies, ecotypes, cultivars and even tissues?.

Small major vein areas and diameters of xylem cells were typical of all marigold cultivars grown in the CdAlon treatment; these characteristics were clearly visible in the study plants grown in the Cd-Pig treatment across all marigold cultivars. This finding was in contrast with a previous study, as $\mathrm{Cd}$ accumulation in vascular bundle of the major vein did not affect xylem vessel diameter in Typha domingensis Pers. ${ }^{34}$. A measure of disorganization and shrinkage of epidermal cells and disorganization of mesophyll and vascular bundle material were observed in Honey cultivar grown in the Cd-Alon treatment (Fig. 2B); although similar observations were made in the American cultivar, they were more modest with slight disorganization in vascular bundle and a small amount of shrinkage in epidermal cells. Such phenomena have caused severe decline of cell viability and a reduction in thickness and breakdown of the palisade and spongy mesophyll layer, mainly as a result of $\mathrm{Zn}$ or Cd stress ${ }^{35}$. Among cultivars grown in amended treatments, only the French cultivar in the Cd-Catt treatment developed small major vein areas, phloem degradation, a small degree of shrinkage in epidermal cells and slight disorganization of mesophyll. To some extent, a disorganized and degraded mesophyll layer caused by Cd exposure can eventually interfere with photosynthetic efficiency, photosystems and other multiprotein complexes (MPCs) in thylakoids, resulting in decreased plant growth and productivity ${ }^{36}$.

Venation patterns of the study plants were observed with a light microscope. The marigold cultivars had slightly different densities and numbers of minor veins; specimens of the Sunshine cultivar grown in the CdLeo treatment exhibited the highest number. Cultivars were ranked in order of decreasing minor vein density as follows: Sunshine $>$ American $>$ Honey $>$ French; ranking as a function of treatments is: Cd-Leo $>$ Cont $>$ CdCatt $>$ Cd-Pig $>$ Cd. Minor veins play a key role in heavy metal mobility, and contaminants primarily assimilate in the leaf mesophyll at the mature stage. High quantities of $\mathrm{Cd}$ can be detected in major veins within the leaf mesophyll and mesophyll tissues during the development period, whereas very low Cd accumulation was found primarily in vascular bundles ${ }^{37,38}$. However, the rate of water and solute (including heavy metal) uptake and transport from veins across the mesophyll to the point of evaporation from aerial parts, depends on plant genotype, hydraulic capacity, and photosynthetic mechanism ${ }^{39}$.

Notably, specialized structures of the epidermis, e.g., trichomes, were found in Honey cultivar grown in CdPig and Cd-Leo treatments as were the American cultivar grown in the Cd-Alon treatment; no such structures developed in any specimens of the French and Sunshine cultivars regardless of treatment type. Increased heavy metal stress can result in enlargement of trichomes, whose structures and size can act as barriers preventing 
heavy metal adsorption and accumulation via leaf surfaces. However, there is still no clear understanding of the mechanism by which trichomes detoxify heavy metals from leaf surfaces. Ricachenevsky et al. ${ }^{40}$ hypothesized their utility regarding metal detoxification in plant leaves, as Arabidopsis thaliana (L.) Heynh. accumulated substantial concentrations of $\mathrm{Zn}$ in trichomes when compared to other plant organs, which may be considered as a key mechanism for alleviating metal toxicity on plant grown in contaminated soils. The presence of trichomes, and their structure and number on leaf surfaces probably depends on several physicochemical and biological factors, including the presence of heavy metals ${ }^{41,42}$.

\section{Conclusions}

We conclude that organic amendments, particularly pig manure, could reduce the deleterious effects of Cd toxicity and support growth performance of the study plants, as indicated by leaf anatomical changes. The obvious results i.e., cell disorganization in vascular bundles and palisade and spongy mesophyll, were found in the $\mathrm{Cd}$-Alon treatment which contained high quantities of $\mathrm{Cd}$ and no organic amendments.

\section{Methods}

Plant materials. Seeds of four marigold cultivars, including T. erecta e.g., Honey, American and Sunshine, and T. patula e.g., French, were purchased from local agricultural shops in Nakhonsawan Province, Thailand. Seeds were sterilized in $10 \%$ sodium hypochlorite $(\mathrm{NaOCl})$ for $1 \mathrm{~min}$ and then germinated in acid-washed sand with total and extractable Cd levels below detectable limits. All seeds were transferred to a greenhouse at the Nakhonsawan Campus, Mahidol University. Conditions in the greenhouse were temperatures within $27-32{ }^{\circ} \mathrm{C}, \sim 65 \%$ relative humidity and $\sim 16,000 \mathrm{~lx}$.

Greenhouse experiments. All experiments were carried out according to ethical principles on plant usage. Prior to planting, all soil samples were oven-dried and passed through a 2 -mm sieve. Then, each organic amendment $(10 \% \mathrm{w} / \mathrm{w})$ i.e., pig and cattle manure and leonardite, was mixed thoroughly with Cd-enriched soil collected from Mae Sot, Tak Province. Treatments were designated as Cd-Pig, Cd-Catt, and Cd-Leo; a Cdenriched soil with no amendment was designated as Cd-Alon. Furthermore, commercial soil amended with

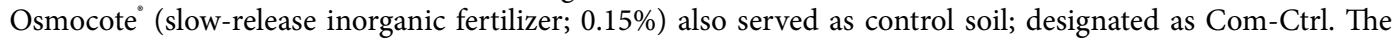
control soil was the mixture of fermented sugarcane bagasse, sugarcane filter cake, soil and dolomite; thus, soil was friable and suitable for plant cultivation. Cd-enriched soils were spiked with $\mathrm{Cd}\left(\mathrm{NO}_{3}\right)_{2}$ to attain measured values of $8.1 \pm 1.6,8.3 \pm 0.7,8.3 \pm 1.0$ and $7.4 \pm 1.0 \mathrm{mg} \mathrm{Cd} \mathrm{kg}^{-1}$ for Cd-Alon, Cd-Pig, Cd-Catt and Cd-Leo treatments, respectively, whereas the control soil, purchased from an agricultural supplies shop, contained low concentrations of $\mathrm{Cd}\left(1.9 \pm 0.2 \mathrm{mg} \mathrm{Cd} \mathrm{kg}{ }^{-1}\right)$. All pots were saturated with deionized water (DI water) for 4 weeks at $70 \%$ water holding capacity. Selected physicochemical properties of the soil samples were analyzed following standard methods e.g., texture, $\mathrm{pH}, \mathrm{CEC}, \mathrm{OM}$, total nitrogen (total N), extractable phosphorus (Ext. P) and extractable potassium (Ext. $\mathrm{K})^{43,44}$.

Marigold seedlings ( $\sim 10 \mathrm{~cm}$ height at 7 days) were transferred to $3.5-\mathrm{kg}$ size plastic pots and placed on greenhouse benches in a randomized complete block design (RCBD). Five replicate pots were used for each treatment, and each replicate comprised a single healthy seedling. The pot treatment systems were designed and modified by the methods of Thongchai et al. ${ }^{8}$.

Cadmium determination. At 3 months after planting, plants were harvested and oven-dried at $70^{\circ} \mathrm{C}$ for 3 days. For each sample, shoots, roots, leaves and whole plant tissues were ground to a fine powder with an IKA A11 basic mill. Plant materials were digested with concentrated $70 \% \mathrm{HNO}_{3}$ and $37 \% \mathrm{HCl}(1: 3)^{43}$. Cd contents in solution were analyzed using flame atomic absorption spectrophotometry (FAAS; Perkin Elmer AAnalyst 200, USA) after filtering with Whatmann ${ }^{\circ}$ No. 42 filter paper.

Two standard reference materials (NIST SRM 2710 a Montana soil and NIST SRM ${ }^{\circ} 1515$ apple leaves) for soil and plant samples were used for the verification of the accuracy of analytical measurements. Percentage recoveries of $\mathrm{Cd}$ for the soil and plant materials were in the range of $90-110 \%$ of the stated content, whereas the relative standard deviation (RSD) ranged from 1.14 to $4.01 \%$.

Light microscopy. At plant maturity the middle portions of the leaves were cut into small pieces $(0.5 \times 0.5$ $\mathrm{cm}^{2}$ ) and immediately fixed in FAA (formaldehyde: glacial acetic acid: 95\% ETOH: distilled water; 5:5:50:40 mL) for $48 \mathrm{~h}$ as described by Johansen ${ }^{45}$. The specimens were gradually dehydrated using a graded series of tertiary butyl alcohol (TBA) and then embedded in paraffin wax. Sections were cut at $5 \mu \mathrm{m}$ with a motorized rotary microtome (ERM 4000, HESTON). The sections were subsequently counterstained with fast green and safranin ${ }^{45}$. After staining, slides were dehydrated, cleaned with fresh xylene and mounted with Permount for examination and photographing structural changes of leaf cells under a Leica DM1000 LED microscope with a Leica MC170 HD camera. Measurement of the lumen diameter of xylem cell, mesophyll thickness, major vein area, and epidermal cell size on both adaxial and abaxial sides of the leaf were carried out using the ImageJ program (version $1.52 \mathrm{v}$ ).

Data analyses. Dry weight of shoots, roots, leaves and whole plant tissues were recorded. Furthermore, relative growth rate (RGR) index data were calculated as described by Phusantisampan et al. ${ }^{46}$, affording a metric of plant growth tolerance in extreme environmental conditions. 
Statistical analysis was carried out using SPSS ${ }^{\circ}$ (SPSS, Chicago, IL) on a Windows-based PC. A one-way ANOVA and least significant difference (LSD) post hoc comparison were used to detect significant differences in the mean values $(p<0.05)$ and are presented as mean \pm standard deviation.

Received: 11 April 2021; Accepted: 26 July 2021

Published online: 05 August 2021

\section{References}

1. Liu, K. et al. Major factor influencing cadmium uptake from the soil into wheat plants. Ecotoxicol. Environ. Saf. 113, 207-213 (2015).

2. Ullah, A., Ma, Y., Li, J., Tahir, N. \& Hussain, B. Effective amendments on cadmium, arsenic, chromium and lead contaminated paddy soil for rice safety. Agronomy 10(3), 359. https://doi.org/10.3390/agronomy10030359 (2020).

3. Palansooriya, K. N. et al. Occurrence of contaminants in drinking water sources and the potential of biochar for water quality improvement: A review. Crit. Rev. Environ. Sci. Technol. 50(6), 549-611 (2020).

4. Moreno-García, B., Guillén, M. \& Quílez, D. Response of paddy rice to fertilization with pig slurry in northeast Spain: Strategies to optimize nitrogen use efficiency. Field Crop Res. 208, 44-54 (2017).

5. Sanli, A., Karadogan, T. \& Tonguc, M. Effects of leonardite applications on yield and some quality parameters of potatoes (Solanum tuberosum L.). Turk. J. Field Crops 18(1), 20-26 (2013).

6. Pereira, P. P. et al. Cadmium tolerance in Schinus molle trees is modulated by enhanced leaf anatomy and photosynthesis. Trees 30, 807-814 (2016).

7. Zheng, Y. et al. Elevated $\mathrm{CO}_{2}$ concentration induces photosynthetic down-regulation with changes in leaf structure, non-structural carbohydrates and nitrogen content of soybean. BMC Plant Biol. 19, 255. https://doi.org/10.1186/s12870-019-1788-9 (2019).

8. Thongchai, A., Meeinkuirt, W., Taeprayoon, P. \& Pichtel, J. Soil amendments for cadmium phytostabilization by five marigold cultivars. Environ. Sci. Pollut. Res. 26, 8737-8747 (2019).

9. Song, X. et al. Detection of cadmium risk to the photosynthetic performance of hybrid Pennisetum. Front. Plant Sci. 10, 798. https:// doi.org/10.3389/fpls.2019.00798 (2019).

10. Kwak, M. J. et al. Surface-based analysis of leaf microstructures for adsorbing and retaining capacity of airborne particulate matter in ten woody species. Forests 11, 946. https://doi.org/10.3390/f11090946 (2020).

11. Chandra, R. \& Kang, H. Mixed heavy metal stress on photosynthesis, transpiration rate, and chlorophyll content in poplar hybrids. For. Sci. Technol. 12(2), 55-61 (2016).

12. Hatamain, M., Nejad, A. R., Kafi, M., Souri, M. K. \& Shahbazi, K. Interaction of lead and cadmium on growth and leaf morphophysiological characteristics of European hackberry (Celtis australis) seedlings. Chem. Biol. Technol. Agric. 7, 9. https://doi.org/ 10.1186/s40538-019-0183-0 (2020).

13. Lindholm-Lehto, P. Biosorption of heavy metals by lignocellulosic biomass and chemical analysis. BioResources 14(2), 4952-4995 (2019).

14. Lisa, S. J., Shethi, K. J. \& Rashid, P. Effects of cadmium on the anatomical structures of vegetative organs of chickpea (Cicer arientinum L.). Dhaka Univ. Biol. Sci. 29(1), 45-52 (2020).

15. Kouhi, S. M. M., Lahouti, M., Ganjeali, A. \& Entezari, M. Anatomical and ultrastructural responses of Brassica napus after longterm exposure to excess zinc. Turkish J. Biol. 40, 652-660 (2016).

16. Havlin, J. L., Beaton, J. D., Tisdale, S. L. \& Nelson, W. L. Soil Fertility and Fertilizers: An Introduction to Nutrient Management (Pearson Education, 2005).

17. Gentili, R., Ambrosini, R., Montagnani, C., Caronni, S. \& Citterio, S. Effect of soil pH on the growth, reproductive investment and pollen allergenicity of Ambrosia artemisiifolia L. Front. Plant Sci. 9, 1335. https://doi.org/10.3389/fpls.2018.01335 (2018).

18. Saengwilai, P., Meeinkuirt, W., Phusantisampan, T. \& Pichtel, J. Immobilization of cadmium in contaminated soil using organic amendments and its effects on rice growth performance. Exp. Health 12, 295-306 (2020).

19. Akimbekov, N. et al. The effect of leonardite-derived amendment on soil microbiome structure and potato yield. Agriculture 10, 147. https://doi.org/10.3390/agriculture10050147 (2020).

20. Rehman, M. Z. et al. Effect of limestone, lignite and biochar applied alone and combined on cadmium uptake in wheat and rice under rotation in an effluent irrigated field. Environ. Pollut. 227, 560-568 (2017).

21. Xu, Y. G., Yu, W. T., Ma, Q. \& Zhou, H. Potential risk of cadmium in a soil-plant system as a result of long-term (10 years) pig manure application. Plant Soil Environ. 61(8), 352-357 (2015).

22. Saengwilai, P., Meeinkuirt, W., Pichtel, J. \& Koedrith, P. Influence of amendments on Cd and Zn uptake and accumulation in rice (Oryza sativa L.) in contaminated soil. Environ. Sci. Pollut. Res. 24(18), 15756-15767 (2017).

23. Gul, I. et al. Comparative effectiveness of organic and inorganic amendments on cadmium bioavailability and uptake by Pelargonium hortorum. J. Soils Sediments 19, 2346-2356 (2019).

24. Gul, I. et al. EDTA-assisted phytoextraction of lead and cadmium by Pelargonium cultivars grown on spiked soil. Int. J Phytoremediat. 21(2), 101-110 (2019).

25. Gul, I., Manzoor, M., Kallerhoff, J. \& Arshad, M. Enhanced phytoremediation of lead by soil applied organic and inorganic amendments: Pb phytoavailability, accumulation and metal recovery. Chemosphere 258, 127405 (2020).

26. Radovanovic, V., Djekic, I. \& Zarkovic, B. Characteristics of cadmium and lead accumulation and transfer by Chenopodium quinoa Will. Sustainability 12, 3789. https://doi.org/10.3390/su12093789 (2020).

27. Gul, I. et al. Plant uptake and leaching potential upon application of amendments in soils spiked with heavy metals (Cd and $\mathrm{Pb})$. J. Environ. Manag. 249, 109408 (2019).

28. Vollenweider, P., Cosio, C., Günthardt-Goerg, M. S. \& Keller, C. Localization and effects of cadmium in leaves of a cadmiumtolerant willow (Salix viminalis L.). Environ. Exp. Bot. 58, 25-40 (2006).

29. Ackin, A., Ackin, A. \& Yildirim, C. Application of fulvic acid modulates photosynthetic pigments and malondialdehyde content in bread wheat (Triticum aestivum cv. Ekiz) to increase resistance to chromium stress. Int. J. Agric. Biol. 23, 142-148 (2020).

30. Fukuda, N. et al. Visible cellular distribution of cadmium and zinc in the hyperaccumulator Arabidopsis halleri ssp. gemmifera determined by 2-D X-ray fluorescence imaging using high-energy synchrotron radiation. Metallomics 12, 193-203 (2020).

31. Martinez, H. E. P. et al. Leaf and stem anatomy of cherry tomato under calcium and magnesium deficiencies. Braz. Arch. Biol. Technol. 63, e20180670 (2020).

32. Luo, J. \& Zhang, Z. Mechanisms of cadmium phytoremediation and detoxification in plants. Crop J. 9(3), 521-529 (2021).

33. Su, Z. et al. Effects of heavy metal: Copper on the ultrastructure of wheat. Chem. Eng. Trans. 61, 289-294 (2017).

34. Oliveira, J. P. V. et al. Cadmium tolerance of Typha domingensis Pers. (Typhaceae) as related to growth and leaf morphophysiology. Braz. J. Biol. 78(3), 509-516 (2018).

35. Al-Zurfi, S. K. L., Alisaw, A. Y. \& Al-Shafai, G. A. A. Anatomical and physiological effects of cadmium in aquatic plant Hydrilla verticillata. Plant Arch. 18(1), 839-846 (2018).

36. Bashir, H., Qureshi, M. I., Ibrahim, M. M. \& Iqbal, M. Chloroplast and photosystems: Impact of cadmium and iron deficiency. Photosynthetica 53(3), 321-335 (2015). 
37. Page, V. \& Feller, U. Heavy metals in crop plants: Transport and redistribution processes on the whole plant level. Agronomy 5, 447-463 (2015).

38. Tian, S. et al. Uptake, sequestration and tolerance of cadmium at cellular levels in the hyperaccumulator plant species Sedum alfredii. J. Exp. Bot. 68(9), 2387-2398 (2017).

39. Brodribb, T. J., Field, T. S. \& Jordan, G. J. Leaf maximum photosynthetic rate and venation are linked by hydraulics. Plant Physiol. 144(4), 1890-1898 (2007).

40. Ricachenevsky, F. K., Punshon, T., Salt, D. E., Fett, J. P. \& Guerinot, M. L. Arabidopsis thaliana zinc accumulation in leaf trichomes is correlated with zinc concentration in leaves. Sci. Rep. 11, 5278 (2021).

41. Karabourniotis, G., Liakopoulos, G., Nikolopoulos, D. \& Bresta, P. Protective and defensive roles of non-glandular trichomes against multiple stresses: Structure-function ordination. J. For. Res. 31, 1-12 (2020).

42. Ngugen, T. Q., Sesin, V., Kisiala, A. \& Emery, R. J. N. Phytohormonal roles in plant responses to heavy metal stress: Implications for using macrophytes in phytoremediation of aquatic ecosystems. Environ. Toxicol. Chem. 40(1), 7-22 (2020).

43. APHA AWWA and WEF (American Public Health Association, American Water Works Association and Water Environment Federation). Standard Methods for the Examination of Water and Wastewater (American Public Health Association, 2005).

44. Sparks, D. L., Page, A. L., Helmke, P. A. \& Loeppert, R. H. Methods of Soil Analysis. Part 3. Chemical methods (Soil Science Society of America, Book series No.5, 1996).

45. Johansen, D. A. Plant Microtechnique (McGraw-Hill Book Co.Ltd, 1940).

46. Phusantisampan, T., Meeinkuirt, W., Saengwilai, P., Pichtel, J. \& Chaiyarat, R. Phytostabilization potential of two ecotypes of Vetiveria zizanioides in cadmium-contaminated soils: Greenhouse and field experiments. Environ. Sci. Pollut. Res. 23, 20027-20038 (2016)

\section{Acknowledgements}

We would like to thank Mr. Julian Pieniazek and Prof. John Pichtel for English language editing.

\section{Author contributions}

A.T. and W.M. conceived the idea and designed experiments in this study. A.T., W.M., P.T. and I.C. were involved in data collection, analysis and interpretation of results. A.T. and W.M. were involved in writing of the manuscript. W.M. gave supervision to this study and approved the final version of the manuscript. All authors reviewed the manuscript.

\section{Competing interests}

The authors declare no competing interests.

\section{Additional information}

Correspondence and requests for materials should be addressed to W.M.

Reprints and permissions information is available at www.nature.com/reprints.

Publisher's note Springer Nature remains neutral with regard to jurisdictional claims in published maps and institutional affiliations.

(c) (i) Open Access This article is licensed under a Creative Commons Attribution 4.0 International cc) License, which permits use, sharing, adaptation, distribution and reproduction in any medium or format, as long as you give appropriate credit to the original author(s) and the source, provide a link to the Creative Commons licence, and indicate if changes were made. The images or other third party material in this article are included in the article's Creative Commons licence, unless indicated otherwise in a credit line to the material. If material is not included in the article's Creative Commons licence and your intended use is not permitted by statutory regulation or exceeds the permitted use, you will need to obtain permission directly from the copyright holder. To view a copy of this licence, visit http://creativecommons.org/licenses/by/4.0/.

(c) The Author(s) 2021 